\title{
Utilization of Origin Bacteria-Pliek $U$ (YNH11 Isolates) in Fermenting Process of Coconut Dregs Cocos (Nucifera L.)
}

\author{
H L Harahap, Yunilas, N Ginting, E Mirwandhono, A H Daulay \\ Animal Production Program, Faculty of Agriculture, Universitas Sumatera Utara, \\ Medan 20155 \\ E-mail: lonahrp@gmail.com
}

\begin{abstract}
Coconut plants are common in Indonesia, which is the second largest copra producer in the world. Coconut dregs has never been used before, as result it is one of large wastes in Indonesia. The main problems of coconut dregs were the content of crude fiber and crude fat which are high and low crude protein. Special attention was needed to improve the nutritional content by using fermentation technology. Fermentation was used in this study by using bacteria which had derived from the coconut plant itself called pliek u, isolate (YNH11). This study was conducted for 3 months starting from April to July 2018 at the Animal Production Laboratory and the Laboratory of Animal Food Nutrition Sciences Faculty of Agriculture, University of North Sumatra. This research was designed using a Completely Randomized Design (CRD) factorial pattern of 3 x 3, with 3 replications where remarked as factor 1 was the various levels of bacterial inoculum YNH11 from pliek u and factor 2 was the duration of fermentation (incubation). the parameters measured were water content, dry ingredient, crude protein, crude fiber, crude fat, and ash content using proximate analysis.

The results showed that coconut pulp fermentation using bacterial origin of pliek $\mathrm{u}$ (isolate YNH11) with the level of inoculum administration and fermentation time had an effect on the measured parameters. it eventually increased water content and crude protein, meanwhile it decresed crude fiber, crude fat, dry ingredient, and ash content as well.
\end{abstract}

\section{Introduction}

Coconut plants (Cocos nucifera L.) are a type of palm plant that has multiple functions because almost all parts of the plant can be utilized. Coconut plantations in Indonesia reach 3,759,397 ha. Sumatra Province is one of the main producers.[1]. Coconut pulp is usually only disposed of or given to other livestock without any process. The main problem of coconut pulp when used as feed ingredients is low crude protein content, crude fat and high crude fiber. [2].

Fermentation is a food processing technology with the help of decomposing microbes which in this study used bacterial isolates from pliek $\mathrm{u}$, which are bacteria derived from coconut. microbes derived from their own substrate have a progressive task in degrading the substrate [3].

The authors are interested in examining the ability of bacteria from pliek $u$ as inoculants in coconut pulp fermentation to improve their quality and nutritional content.

\section{Materials and Methods}

This study lasted for 3 months which was carried out from April to July 2018 at the Animal Production Laboratory and the Laboratory of Animal Food Nutrition Sciences, Faculty of Agriculture, University of North Sumatra.

The materials used were YNH11 isolates from pliek u [4], coconut pulp, materials to rejuvenate bacteria, namely the culture media of Nutrient agar (NA) and Nutrient Broth (NB), the ingredients in making liquid medium consisting of from aquades, $1 \%$ mix minerals, $0.5 \%$ urea, $1 \%$ molasses and $2 \%$ bran, (Yunilas, 2016), and laboratory materials including catalysts (selenium and sodium sulfate), $\mathrm{H} 2 \mathrm{SO} 4,4 \% \mathrm{H} 3 \mathrm{BO} 4$, indicator, $45 \% \mathrm{NaOH}, 0.1 \mathrm{~N}$. $\mathrm{HCl} \mathrm{N}$-Hexan fat solvent, $0.3 \mathrm{ml} \mathrm{H} 2 \mathrm{SO} 450 \mathrm{ml}$, $1.5 \mathrm{~N} \mathrm{NaOH} 25 \mathrm{ml}, 25 \mathrm{ml}$ acetone, and $100 \mathrm{ml}$ hot water.

The tools used in this study were autoclaves, petri dishes, test tubes, test tube shelves, bunsen, hot plate, ose needle, weighing scale, $1 \mathrm{~kg}$ clear plastic, and laboratory tools in proximate analysis including weighing bottles, exator, oven, porcelain crussibel, electric furnace, erlenmeyer flask, buchner funnel, filter flask, soxhlet, upright cooler, destructive pumpkin. 


\subsection{Research method}

This research is usng RAL factorial with $3 \times 3$ pattern, and 3 replication

Factor $1=$ Various doses of YNH11 bacterial inoculum from pliek

$\mathrm{P} 1=1 \%$

$\mathrm{P} 2=3 \%$

$\mathrm{P} 3=5 \%$

Factor $2=$ fermentation time (incubation)

$\mathrm{W} 1=3$ hari

$\mathrm{W} 2=6$ hari

$\mathrm{W} 3=9$ hari

This replication got from this form:

a.b $(\mathrm{r}-1) \geq 15$

$3.3(\mathrm{r}-1) \geq 15$

$9 \mathrm{r}-9 \geq 15$

$9 \mathrm{r} \geq 15+9$

$r \geq 24 / 9$

$\mathrm{r} \geq 2,6$

$=3$

The linear methode is used :

$\mathrm{Y}_{\mathrm{ijk}}=\mu+\alpha_{\mathrm{i}}+\beta_{\mathrm{i}}+(\alpha \beta)_{\mathrm{ij}}+\varepsilon_{\mathrm{ijk}}$

information:

$\mathrm{Y}_{\mathrm{ijk}} \quad=$ The research in one researh to- $\mathrm{k}$ with combination taraf to- $\mathrm{i}$ from factor $\mathrm{A}$ and taraf to-j from factor B

$\mu \quad=$ mean population

$\alpha_{\mathrm{i}} \quad=$ influences taraf to-i from factor $\mathrm{A}$

$\beta_{\mathrm{i}} \quad=$ influences taraf to-j from factor $\mathrm{B}$

$(\alpha \beta)_{\mathrm{ij}} \quad=$ influences taraf to $-\mathrm{I}$ from factor $\mathrm{A}$ and taraf to-j from factor $\mathrm{B}$

$\varepsilon_{\mathrm{ijk}} \quad=$ Random influences from one research to-k which get combination ij [5]

Table. 1. The design will be used is :

\begin{tabular}{lcccc}
\hline \multirow{2}{*}{ Factor I } & $\mathrm{R}$ & \multicolumn{3}{c}{ Factor II } \\
\cline { 3 - 5 } & & $\mathrm{W}_{1}(2$ days $)$ & $\mathrm{W}_{2}(4$ days $)$ & $\mathrm{W}_{3}(6$ days $)$ \\
\hline \multirow{3}{*}{$\mathrm{A}_{1}=1 \%$} & $\mathrm{U}_{1}$ & $\mathrm{~A}_{1} \mathrm{~W}_{1} \mathrm{U}_{1}$ & $\mathrm{~A}_{1} \mathrm{~W}_{2} \mathrm{U}_{1}$ & $\mathrm{~A}_{1} \mathrm{~W}_{3} \mathrm{U}_{1}$ \\
& $\mathrm{U}_{2}$ & $\mathrm{~A}_{1} \mathrm{~W}_{1} \mathrm{U}_{2}$ & $\mathrm{~A}_{1} \mathrm{~W}_{2} \mathrm{U}_{2}$ & $\mathrm{~A}_{1} \mathrm{~W}_{3} \mathrm{U}_{2}$ \\
& $\mathrm{U}_{3}$ & $\mathrm{~A}_{1} \mathrm{~W}_{1} \mathrm{U}_{3}$ & $\mathrm{~A}_{1} \mathrm{~W}_{2} \mathrm{U}_{3}$ & $\mathrm{~A}_{1} \mathrm{~W}_{3} \mathrm{U}_{3}$ \\
$\mathrm{~A}_{2}=3 \%$ & $\mathrm{U}_{1}$ & $\mathrm{~A}_{2} \mathrm{~W}_{1} \mathrm{U}_{1}$ & $\mathrm{~A}_{2} \mathrm{~W}_{2} \mathrm{U}_{1}$ & $\mathrm{~A}_{2} \mathrm{~W}_{3} \mathrm{U}_{1}$ \\
& $\mathrm{U}_{2}$ & $\mathrm{~A}_{2} \mathrm{~W}_{1} \mathrm{U}_{2}$ & $\mathrm{~A}_{2} \mathrm{~W}_{2} \mathrm{U}_{2}$ & $\mathrm{~A}_{2} \mathrm{~W}_{3} \mathrm{U}_{2}$ \\
& $\mathrm{U}_{3}$ & $\mathrm{~A}_{2} \mathrm{~W}_{1} \mathrm{U}_{3}$ & $\mathrm{~A}_{2} \mathrm{~W}_{2} \mathrm{U}_{3}$ & $\mathrm{~A}_{2} \mathrm{~W}_{3} \mathrm{U}_{3}$ \\
& $\mathrm{U}_{1}$ & $\mathrm{~A}_{3} \mathrm{~W}_{1} \mathrm{U}_{1}$ & $\mathrm{~A}_{3} \mathrm{~W}_{2} \mathrm{U}_{1}$ & $\mathrm{~A}_{3} \mathrm{~W}_{3} \mathrm{U}_{1}$ \\
$\mathrm{~A}_{3}=5 \%$ & $\mathrm{U}_{2}$ & $\mathrm{~A}_{3} \mathrm{~W}_{1} \mathrm{U}_{2}$ & $\mathrm{~A}_{3} \mathrm{~W}_{2} \mathrm{U}_{2}$ & $\mathrm{~A}_{3} \mathrm{~W}_{3} \mathrm{U}_{2}$ \\
& $\mathrm{U}_{3}$ & $\mathrm{~A}_{3} \mathrm{~W}_{1} \mathrm{U}_{3}$ & $\mathrm{~A}_{3} \mathrm{~W}_{2} \mathrm{U}_{3}$ & $\mathrm{~A}_{3} \mathrm{~W}_{3} \mathrm{U}_{3}$ \\
\hline
\end{tabular}

\subsection{Measured Parameter}

The parameters of the study were moisture content, dry matter, protein base, crude fiber, crude fat, ash content.

\section{Moisture Content}

Moisture content $=($ bottle weight + weight sample $)-$ weight after oven $\times 100 \%$

Dry Matter

$$
\text { Weight sample }
$$

$\% \mathrm{BK}=100 \%-\%$ moisture Content

Crude Protein

$\% \mathrm{PK}=\underline{\text { (blank sample titrant }) \times \mathrm{N} \mathrm{HCl} \times 0,014 \times 6,25} \times 100 \%$

$$
\text { Weight sample }
$$




\section{Crude Fiber}

$\% \mathrm{CF}=$ weight after tanur- filter paper weight $\times 100 \%$

\section{Crude Fat}

$$
\text { Weight sample }
$$

$$
\begin{aligned}
& \% \mathrm{CF} \%=\text { weight after oven } 1 \text { - weight after oven } 2 \times 100 \% \\
& \text { weight after oven } 1 \text { - weight filter paper }
\end{aligned}
$$

\section{Ash Content}

$\% \mathrm{AC}=\underline{\text { (weight after tanur })-(\text { weight Crussibel porselin })} \times 100 \%$

\section{Weight sample}

\section{Implementation Research}

This research does in three steps. The first step is rejuvenation bacteria, the second step is fermentation process with 3 level bacterias, $1 \%, 3 \%, 5 \%$. And the last step is analysis process use proximate anlysis.

\subsection{Data Analysis}

This data will be analyzing by RAL factorial and if it got the real data, will continue with Duncan.

\section{Results and Discussion}

\section{Moisture Content}

Table 2. . Moisture Content of coconut dregs after fermentation process

\begin{tabular}{lcccr}
\hline \multirow{2}{*}{ Bacterial dose } & \multicolumn{3}{c}{ Fermentation time (days) } & \multirow{2}{*}{ Average } \\
\cline { 2 - 4 } & $\mathrm{W} 1$ & $\mathrm{~W} 2$ & $\mathrm{~W} 3$ & $12.71^{\mathrm{C}}$ \\
P1 & 12.27 & 12.73 & 13.14 & $12.82^{\mathrm{B}}$ \\
P2 & 12.39 & 12.80 & 13.28 & $12.93^{\mathrm{A}}$ \\
\hline P3 & 12.46 & 12.93 & 13.40 & \\
\hline Average & $12.37^{\mathrm{C}}$ & $12.83^{\mathrm{B}}$ & $13.27^{\mathrm{A}}$ & \\
\hline
\end{tabular}

Information: The different superscript in the same row line and coloumn show the real differences $(\mathrm{P}<0,01)$.

Based on duncan test there is increasing of moisture content seen from inocculum bacteria after fermentation, we can find the highest average in P3 from $11,38 \%$ be $12,93 \%$ or as big as 11,98 $\%$ and the lowest average is P1 from $11,38 \%$ be 12,71 or asa big as $10,46 \%$, and seen from fermentation time, we can find the highest average in W3 from $11,38 \%$ be $13,27 \%$ or as big as 16,60 $\%$ and the lowest average is $\mathrm{W} 1$ from $11,38 \%$ be $12,37 \%$ or asa big as $8,69 \%$.

This analysis can be predictable because in processing fermentation, there is a side result are water vapor and warm, so if the higher dose we give, the water vapor we got. This statement is same like [6] in their research said that in processing of yeast fermentation in giving dose of that, the water vapor always increase as much as dose given.

\section{Dry Matter}

Table 3. Dry Matter of Coconut Dregs after fermentation process

\begin{tabular}{lcccc}
\hline \multirow{2}{*}{ Bacterial dose } & \multicolumn{3}{c}{ Fermentation time (days) } & \multirow{2}{*}{ Average } \\
\cline { 2 - 4 } & $\mathrm{W} 1$ & $\mathrm{~W} 2$ & $\mathrm{~W} 3$ & \\
\hline P1 & 87.72 & 87.27 & 86.76 & $87.25^{\mathrm{A}}$ \\
P2 & 87.61 & 87.19 & 86.47 & $87.07^{\mathrm{B}}$ \\
P3 & 87.53 & 87.06 & 86.38 & $86.99^{\mathrm{C}}$ \\
\hline Average & $87.62^{\mathrm{A}}$ & $87.17^{\mathrm{B}}$ & $86.99^{\mathrm{C}}$ & \\
\hline
\end{tabular}

Information: The different superscript in the same row line and coloumn show the real differences $(\mathrm{P}<0,01)$.

Based on duncan test there is decreasing of dry matter seen from inocculum bacteria after fermentation, we can find the highest average in P3 from $88,62 \%$ be $86,99 \%$ or as big as $1,83 \%$ and the lowest average is $\mathrm{P} 1$ from $88,62 \%$ be $87,25 \%$ or asa big as $1,54 \%$, and seen from fermentation 
time, we can find the highest average in W3 from $88,62 \% \%$ be $86,99 \%$ or as big as $1,83 \%$ and the lowest average is $\mathrm{W} 1$ from $88,62 \%$ be $87,62 \%$ or asa big as $1,12 \%$.

This analysis can be predictable because the highest dose we give, will decrease the Dry Matter because there is the hydrolysis substrate that change into simple substrate and produce the water vapor, so the dry matter is decreasing.

\section{Crude Protein}

Table 4. Crude protein of Coconut Dregs after fermentation process

\begin{tabular}{lcccr}
\hline \multirow{2}{*}{ Bacterial dose } & \multicolumn{3}{c}{ Fermentation time (days) } & \multirow{2}{*}{ Average } \\
\cline { 2 - 4 } & $\mathrm{W}_{1}$ & $\mathrm{~W}_{2}$ & $\mathrm{~W}_{3}$ & 7.48 \\
\hline $\mathrm{P}_{1}$ & $6.73^{\mathrm{Aa}}$ & $7.64^{\mathrm{Ab}}$ & $8.08^{\mathrm{Ab}}$ & 7.62 \\
$\mathrm{P}_{2}$ & $6.81^{\mathrm{Ba}}$ & $7.84^{\mathrm{Bb}}$ & $8.22^{\mathrm{Ba}}$ & 7.77 \\
$\mathrm{P}_{3}$ & $6.94^{\mathrm{Ba}}$ & $7.93^{\mathrm{Bb}}$ & $8.44^{\mathrm{Aa}}$ & \\
\hline Average & 6.82 & 7.8 & 8.24 &
\end{tabular}

Information: The different superscript in the same row line and coloumn show the real differences $(\mathrm{P}<0,05)$.

Based on duncan test there is increasing of crude protein from the interaction of inoculum bacteria and fermentation time after fermentation, we can find the highest average in P3W3 from 5.89 $\%$ be $8.44 \%$ or as big as $30.2 \%$ and the lowest average is $\mathrm{P} 1 \mathrm{~W} 1$ from $5.89 \%$ be $6.73 \%$ or asa big as 12,48 .

This analysis can be predictable because when fermentation processing, many bacterias splitt and produce other protein call one cell protein (PST). So the contain of crude protein will add by existance of one cell protein. This statement accord to [7] told that bacteria is a procaritoc cell that grow with binary cleavage.

\section{Crude Fiber}

Table 5. Crude Fiber of Coconut Dregs after fermentation process

\begin{tabular}{lcccc}
\hline \multirow{2}{*}{ Bacterial dose } & \multicolumn{3}{c}{ Fermentation time (days) } & \multirow{2}{*}{ Average } \\
\cline { 2 - 4 } & $\mathrm{W}_{1}$ & $\mathrm{~W}_{2}$ & $\mathrm{~W}_{3}$ & 20.84 \\
\hline $\mathrm{P}_{1}$ & $24.87^{\mathrm{Bb}}$ & $19.87^{\mathrm{Bb}}$ & $17.78^{\mathrm{Ba}}$ & 20.60 \\
$\mathrm{P}_{2}$ & $24.68^{\mathrm{Bb}}$ & $19.72^{\mathrm{Bb}}$ & $17.60^{\mathrm{Ba}}$ & 20.48 \\
$\mathrm{P}_{3}$ & $24.40^{\mathrm{Ab}}$ & $19.60^{\mathrm{Ab}}$ & $17.45^{\mathrm{Aa}}$ & \\
\hline Average & 24.65 & 19.73 & 17.61 &
\end{tabular}

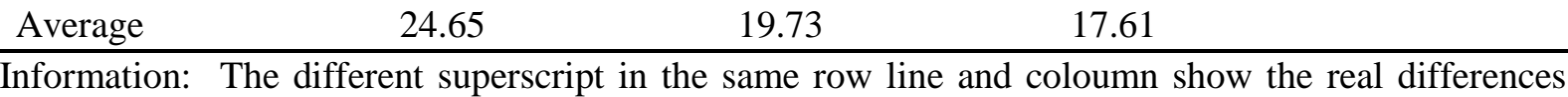
$(\mathrm{P}<0,01)$.

Based on duncan test there is decreasing of crude fiber from the interaction of inoculum bacteria and fermentation time after fermentation, we can find the highest average in P3W3 from $27.99 \%$ be $17.45 \%$ or as big as $37.65 \%$ and the lowest average is P1W1 from $27.99 \%$ be $24.87 \%$ or asa big as $11.14 \%$.

This analysis can be predictable because the highest we dose, will got the lowest crude fiber, because will produce more lifase enzym that degrades the cellulose and lignicellulose at th e limit time. Thus statement accord to [8] told that the decreasing of crude fiber happens when the activity of microba along fermentation that can produce the degradation bacteria of cellulose substrate.

\section{Crude Fat}

Based on duncan test there is decreasing of Crude fat seen from inocculum bacteria after fermentation, we can find the highest average in P3 from 10,87\% be $9,10 \%$ or as big as $16,28 \%$ and the lowest average is P1 from $10,87 \%$ be $9,33 \%$ asa big as $14,16 \% \%$, and seen from fermentation time, we can find the highest average in $\mathrm{W} 3$ from $10,87 \%$ be $8,84 \%$ or as big as $18,67 \%$ and the lowest average is $\mathrm{W} 1$ from $10,87 \%$ be $9,56 \%$ or asa big as $12,05 \%$. 
Table 6. Crude Fat of Coconut Dregs after fermentation process

\begin{tabular}{lcccr}
\hline \multirow{2}{*}{ Bacterial dose } & \multicolumn{3}{c}{ Fermentation time (days) } & \multirow{2}{*}{ Average } \\
\cline { 2 - 4 } & W1 & W2 & W3 & $9.33^{\mathrm{A}}$ \\
P1 & 9.67 & 9.36 & 8.95 & $9.24^{\mathrm{B}}$ \\
P2 & 9.58 & 9.29 & 8.86 & $9.10^{\mathrm{C}}$ \\
P3 & 9.44 & 9.17 & 8.70 & \\
\hline Average & $9.56^{\mathrm{A}}$ & $9.27^{\mathrm{B}}$ & $8.84^{\mathrm{C}}$ & \\
\hline
\end{tabular}

Information: The different superscript in the same row line and coloumn show the real differences $(\mathrm{P}<0,01)$.

This analysis can be predictable because the highest crude fat produced, it will influence the producing of lipase enzym that use to degradation of lipase. And can decrease the value of crude fat. In other ways told that fermentation processing at 9 days time (the last fermentation process) has not entered to stationer time that make the bacteria still want to grow and develope and produce mopre lipase enzym.

\section{Ash Content}

Table 7. Ash Content of Coconut Dregs after fermentation process

\begin{tabular}{lcccc}
\hline \multirow{2}{*}{ Isolat bakteri } & \multicolumn{3}{c}{ Lama Fermentasi } & \multirow{2}{*}{ Rataan } \\
\cline { 2 - 4 } & $\mathrm{W}_{1}$ & $\mathrm{~W}_{2}$ & $\mathrm{~W}_{3}$ & \\
\hline $\mathrm{P}_{1}$ & $3.88^{\mathrm{Ab}}$ & $3.70^{\mathrm{Bb}}$ & $3.35^{\mathrm{Aa}}$ & 3.64 \\
$\mathrm{P}_{2}$ & $3.82^{\mathrm{Ab}}$ & $3.53^{\mathrm{Ab}}$ & $3.31^{\mathrm{Aa}}$ & 3.55 \\
$\mathrm{P}_{3}$ & $3.77^{\mathrm{Ab}}$ & $3.44^{\mathrm{Ab}}$ & $3.28^{\mathrm{Aa}}$ & 3.49 \\
\hline Rataan & 3.82 & 3.55 & 3.31 & \\
\hline
\end{tabular}

Information: The different superscript in the same row line and coloumn show the real differences $(\mathrm{P}<0,01)$.

Based on duncan test there is decreasing of Ash Content from the interaction of inoculum bacteria and fermentation time after fermentation, we can find the highest average in P3W3 from 3.93 $\%$ be $3.28 \%$ or as big as $16.53 \%$ and the lowest average is P1W1 from $3.93 \%$ be 3,88 \% or asa big as $1.27 \%$.

The decreasing of ash content happens in fermentation process will increase organic material cause of the degradation substrate of microba. The little organic material degrated, the lower decreasing of ash content. This statement accord to [9] show that the crude fiber and ash content have a positive connection that will influence from the increasing of crude fiber will increase the ash content.

\section{Conclusion}

The results showed that coconut pulp fermentation using bacterial origin of pliek u (isolate YNH11) with the level of inoculum administration and fermentation time had an effect on the measured parameters. it eventually increased water content and crude protein, meanwhile it decresed crude fiber, crude fat, dry ingredient, and ash content as well.

The result also show that the dose of bacteria will work optimal in $5 \%$ dose and 9 days fermentation time, and got the best result. 


\section{References}

[1] Direktorat Jenderal Perkebunan. 2014. Statistik Perkebunan Kelapa Sawit Indonesia 2013-2015. Direktorat Jenderal Perkebunan. Jakarta.

[2] Hidayat, et al. (2006). Mikrobiologi Industri. C.V Andi Offset. Yogyakarta

[3] Yunilas, Nurzainah Ginting, dan Hasnudi. 2017 Probiotik Pliek U sebagai BioaktivatorPakan Ternak Berbasis Limbah Sawit (Solid). Laporan Akhir Penelitian Dasar. Fakultas Pertanian. Universitas Sumatera Utara

[4] Yunilas, Lili Wanty, Yetti Marlida, dan Irsan Riyanto. 2013 Potency of indigenousBacteria from palm oil waste in degrads lignicellulose as a source of inoculum fermented to hight fibre freed. Pakistan jounal of Nutrition. 12 (9) : 851-853

[5] Jawetz, E, J. melnick, et al. 2005. Jakarta: EGC Jawetz, melnick \& Adelberg

[6] Bolsen K dan Sapienza. 1993. Teknologi Silase: Penanaman, pembuatan dan pem beriannya pada ternak. Penerjemah Riri BS. Martoyoedo. Kansas. Dioneer Seeds.

[7] Suprihatin. 2010. Teknologi Fermentasi. UNESA Press. Surabaya.

[8] Yunilas, Lili Wanty, Yetti Marlida, dan Irsan Riyanto. 2013 Potency of indigenous Bacteria from palm oil waste in degrads lignicellulose as a source of inoculum fermented to hight fibre freed. Pakistan jounal of Nutrition. 12 (9) : 851-853

[9] Wibowo, A. H. 2010. Pendugaan Kandungan Nutrien Dedak Padi Berdasarkan Karekteristik Sifat Fisik. Thesis. Sekolah Pascasarjana, Fakultas Peternakan. Institut Pertanian Bogor. Bogor 